\title{
Effect of Microclimatic Regimes and Nitrogen Management on Growth and Yield of Direct Seeded Rice (Oryza sativa L.) under Rainfed Condition
}

\author{
P. Ahmed ${ }^{1 *}$, M. Saikia ${ }^{2}$, K. Pathak ${ }^{2}$, S. Dutta ${ }^{3}$ and A.C. Sarmah ${ }^{4}$ \\ ${ }^{1}$ SCS College of Agriculture, Dhubri, Assam Agricultural University, \\ Rangamati- 783376, Assam, India \\ ${ }^{2}$ Directorate of Research (Agri), ${ }^{3}$ Department of Soil Science, Assam Agricultural University, \\ Jorhat- 785013, Assam, India \\ ${ }^{4}$ RARS, Assam Agricultural University, Shillongani, Nagaon, Assam, India \\ *Corresponding author
}

\begin{abstract}
A B S T R A C T
\section{Keywords}

Micro climatic regimes, Nitrogen management, Vermicompost, Direct seeded rice

Article Info

Accepted:

12 January 2019

Available Online:

10 February 2019

A field experiment was conducted during autumn season of 2016-17 and 2017-18 to study the effect of micro climatic regimes and nitrogen management on growth, yield attributes and yield of direct seeded rice. The experiment was laid out in factorial randomized block design with three replications. The treatment consisted of four micro climatic regimes i.e., $\mathrm{M}_{1}, \mathrm{M}_{2}, \mathrm{M}_{3}, \mathrm{M}_{4}$ and $\mathrm{N}$ management $\left(\mathrm{N}_{1}: 100 \% \mathrm{RDF}\right.$ of $\mathrm{N}$ as inorganic; $\mathrm{N}_{2}: 75 \% \mathrm{~N}$ as inorganic $+0.5 \mathrm{t} / \mathrm{ha}$ vermicompost (V.C.); $\mathrm{N}_{3}: 50 \% \mathrm{~N}$ as inorganic $+1.0 \mathrm{t} / \mathrm{ha}$ V.C.; $\mathrm{N}_{4}$ : $25 \% \mathrm{~N}$ as inorganic $+1.5 \mathrm{t} / \mathrm{ha}$ V.C. $)$. The crop sown early on 1 April $\left(\mathrm{M}_{1}\right)$ showed significantly superior in growth parameters than the crop sown late on 15 May $\left(\mathrm{M}_{4}\right)$. Application of $50 \% \mathrm{~N}$ as inorganic along with vermicompost@1.0 t/ha resulted significantly highest yield attributes and grain as well as straw yield as compared to other nitrogen management practices.
\end{abstract}

\section{Introduction}

Rice (Oryza sativa L.) constitutes one of the most important staple foods of over half of the world's population. In India, it covers an area 42.27 million ha with an average productivity of $24.90 \mathrm{q} / \mathrm{ha}$. India is the second largest producer (105.24 $\mathrm{m} \mathrm{t}$ ) next to China (144 m t) (FAOSTAT Database, 2014). In Assam also, rice is the dominant crop covering about 24.84 lakh ha with a production of 51.25 lakh MT and productivity of $20.87 \mathrm{q} / \mathrm{ha}$. Though sali rice (winter rice) is the predominant crop of the state, a considerable rice area $(10 \%)$ is presently occupied by the $a h u$ rice (autumn rice) with a production of 2.56 lakh MT (Economic Survey of Assam, 2017-18).

It is well known fact that crop performance is the result of combined effect of genetic traits which it inherits and the environment to 
which it is exposed. Environmental condition acts as a factor, affecting yield related properties of rice in different planting dates. Proper planting time influences crop growth and ultimately lead to better yield.

Various studies have revealed that delayed sowing affect various physiological as well as yield related parameters which ultimately lead to the poor production of the grain yield. Delayed planting caused a reduction in grain yield due to shortening of the growth period duration (Bashir et al., (2010).

Efficient $\mathrm{N}$ fertilizer management is critical for the economic production of rice. Nitrogen fertilizer management should be in such a way that $\mathrm{N}$ supplied in organic or inorganic form but the total amount should be sufficient for the economic production of the crop. Combination of organic and inorganic sources of nutrients is necessary for sustainable agriculture that can ensure food production with high quality. Keeping this in view, the present investigation was aimed to study the effect of micro climatic regimes and nitrogen management on growth and yield of direct seeded rice under rainfed condition of Tinsukia, Assam.

\section{Materials and Methods}

The field experiments were conducted at the farm of KVK of Tinsukia lies in between $27^{0} 31^{\prime} 10^{\prime \prime} \mathrm{N}$ Latitude and $95^{\circ} 21^{\prime} 09^{\prime \prime} \mathrm{E}$ Longitude and at an elevation of 147.83 meter above the mean sea level during 2016-17 and of 2017-18. The soil was sandy clay loam having $\mathrm{pH}$ of 5.12 and 5.23 with high in organic carbon $0.85 \%$ and $0.90 \%$, medium in available nitrogen $298.75 \mathrm{~kg} / \mathrm{ha}$ and 310.45 $\mathrm{kg} / \mathrm{ha}$ and phosphorus $25.92 \mathrm{~kg} / \mathrm{ha}$ and 26.13 $\mathrm{kg} / \mathrm{ha}$ and very low in available potassium $33.5 \mathrm{~kg} / \mathrm{ha}$ and $34.4 \mathrm{~kg} / \mathrm{ha}$ at the start of the experiment in 0 to $15 \mathrm{~cm}$ soil layer during 2016-17 and 2017-18, respectively.. The experiment was laid out in factorial RBD with 3 replications. The treatments consisted of four micro climatic regimes i.e., $\mathrm{M}_{1}, \mathrm{M}_{2}, \mathrm{M}_{3}$, $\mathrm{M}_{4}$ and $\mathrm{N}$ management $\left(\mathrm{N}_{1}: 100 \% \mathrm{RDF}\right.$ of $\mathrm{N}$ as inorganic; $\mathrm{N}_{2}: 75 \% \mathrm{~N}$ as inorganic +0.5 t/ha vermicompost (V.C.); $\mathrm{N}_{3}: 50 \% \mathrm{~N}$ as inorganic +1.0 t/ha V.C., $\mathrm{N}_{4}: 25 \% \mathrm{~N}$ as inorganic $+1.5 \mathrm{t} / \mathrm{ha}$ V.C.).

The crop was fertilized with the application of $40: 20: 20 \mathrm{~kg} / \mathrm{ha}$ of $\mathrm{N}, \mathrm{P}_{2} \mathrm{O}_{5}$ and $\mathrm{K}_{2} \mathrm{O}$ in the form urea, single super phosphate and muriate of potash, respectively. Full dose of $\mathrm{P}_{2} \mathrm{O}_{5}$ and $\mathrm{K}_{2} \mathrm{O}$ and $1 / 3^{\text {rd }}$ dose of $\mathrm{N}$ were applied just before sowing as per the treatments. Remaining $2 / 3^{\text {rd }}$ dose of $\mathrm{N}$ were top dressed in two equal splits at 20-25 days and 40-45 days after sowing. Vermicompost were incubated with Azotobacter and phosphorous solubilizing bacteria (PSB) for 15 days @ 0.2 $\%(\mathrm{w} / \mathrm{w})$ and Incubated vermicompost were applied at a specified rate as per the treatments. The micro climatic regimes were developed by sowing the crops in different dates. Rice (variety 'Inglongkiri') seeds were sown as direct seeding method in lines manually with an inter-row spacing of $20 \mathrm{~cm}$ @ $75 \mathrm{~kg} / \mathrm{ha}$.

Agronomic management practices and plant protection measures were followed as per the recommendation. Observation on various growth parameters $v i z$, plant height, dry matter production (g/plant) at harvest and leaf area index (LAI) at 60 and 90 days after sowing and yield attributes were recorded at harvest following standard procedure.

At maturity, the crop was harvested from the whole plot excluding border lines and rice yield was determined. The results of both the years were more or less similar and hence two years data were pooled and analyzed statistically to draw suitable inference as per standard ANOVA technique described by Panse and Sukhatme (1985). 


\section{Results and Discussion}

\section{Effect of micro climatic regimes}

\section{Growth parameters}

Results revealed that all the growth parameters were significantly affected by different micro climatic regimes (Table 1). The highest plant height $(140.2 \mathrm{~cm})$ was recorded in the crop sown on 1 April $\left(\mathrm{M}_{1}\right)$, whereas the lowest plant height $(124.2 \mathrm{~cm})$ was recorded in the crop sown on 15 May $\left(\mathrm{M}_{4}\right)$. The shorter plant might be due to the decrease in length of the vegetative phase with every successive 15 days delay in sowing. Similar results were also reported by Rai and Kushwaha (2008) and Vishwakarma et al., (2016).

The crop sown on 1 April $\left(\mathrm{M}_{1}\right)$ recorded significantly the highest dry matter production at harvest (152.9 g/plant), LAI at 60 DAS (4.24) and LAI at 90 DAS (3.83) and progressively reduced with delay in sowing. Whereas the lowest value of dry matter production at harvest (130.8 g/plant), LAI at 60 DAS (3.48) and LAI at 90 DAS (3.49) was recorded on 15 May $\left(\mathrm{M}_{4}\right)$.

This might be due to favourable weather conditions in micro climatic regimes $\mathbf{M}_{1}$. These results were in conformity with Dawadi and Chaudhary (2013). They observed that rice crop sown on early dates produced significantly higher plant height, higher number of tiller $/ \mathrm{m}^{2}$, leaves/tiller, leaf area index and total dry matter as compared to the sowing of crop on the later dates.

In the present study, 15 days delay in sowing adversely affect normal functions and maturity duration of actively growing plants there by resulting in reduced growth parameters. The results corroborate with those of Khalifa (2009) and Singh et al., (2012).

\section{Yield attributes and yield}

All the yield attributes were significantly influenced by micro climatic regimes (Table 2). Results revealed that the crop sown on 1 April $\left(\mathrm{M}_{1}\right)$ produced significantly higher number of effective tiller/running metre (65.2), total grains/panicle (93.0), filled grains/panicle (73.0) and test weight (20.35g) than other micro climatic regimes. Amongst the micro climatic regimes, micro climatic regime, i.e., 15 May $\left(\mathrm{M}_{4}\right)$ recorded the lowest in all the yield attributing characters with number of effective tiller/metre (56.4), total grains/panicle (79.5), filled grains/panicle ( 63.9) and test weight (17.54 g). The increase in number of effective tillers might be due to favourable environmental condition like temperature, rainfall, relative humidity etc. which enabled the plant to improve its growth and development compared to other micro climatic regimes. These results were in conformity with Akbar et al., (2010). They reported that total number of productive tillers gradually decreased as the sowing was delayed after $20^{\text {th }}$ June. Dawadi and Chaudhary (2013) also reported higher number of effective tillers in early sown aerobic rice.

Similarly the crop grown in 1 April $\left(\mathrm{M}_{1}\right)$ showed superiority in terms of total grains/panicle, filled grains/panicle and test weight as compared to the crop grown in 15 May $\left(\mathrm{M}_{4}\right)$. The delay of 15 days 1 April $\left(\mathrm{M}_{1}\right)$ significantly reduced all the yield attributes. The superiority of higher yield attributes in early sowing as compared to delayed sowing was also reported by Bashir et al., (2010). They reported that the number of kernel/panicle showed better response in early sowing compared to late sowing. Late sowing shortened the growth period of the plant which reduced the leaf area, length of panicle and number of kernels/panicle than early sown crop. They also reported that a thousand 
grain weight decreased gradually with delay in planting time.

The data showed that the highest grain yield of $30.53 \mathrm{q} / \mathrm{ha}$ and straw yield of $55.68 \mathrm{q} / \mathrm{ha}$ and the lowest grain yield of $24.14 \mathrm{q} / \mathrm{ha}$ and straw yield $47.77 \mathrm{q} / \mathrm{ha}$ was recorded in $\mathrm{M}_{1}$ and $\mathrm{M}_{4}$, respectively. The yield reduction of $20.93 \%$ was observed due to 45 days delay in sowing from $\mathrm{M}_{1}$ to $\mathrm{M}_{4}$. The decreasing trend in the grain yield in delayed sowing might be associated with significantly lower number of productive tillers $/ \mathrm{m}^{2}$, less number of filled grains/panicle and low 1000-grain weight. The higher paddy yield in $\mathbf{M}_{1}$ was attributed to more number of productive tillers, more number of grains/panicle and increased 1000 grain weight (Table 2). Similar findings were also reported by Dahiya et al., (2017). They reported that early sowing dates resulted in the maximum number of panicle $/ \mathrm{m}^{2}$, total florets/panicle, 1000 grain weight and paddy yield compared to delayed sowing.

\section{Effect of $\mathbf{N}$ management}

\section{Growth parameters}

Different nitrogen management practices brought about significant variation in respect of plant height and dry matter production at harvest and LAI at 60 and 90 DAS, respectively (Table 1). Application of $75 \% \mathrm{~N}$ as inorganic +0.5 t/ha V.C. $\left(\mathrm{N}_{2}\right)$ resulted in significantly higher plant height of $135.5 \mathrm{~cm}$ which was statistically at par with application of $50 \% \mathrm{~N}$ as inorganic +1.0 t/ha V.C $\left(\mathrm{N}_{3}\right)$ with a plant height of $134.1 \mathrm{~cm}$.

However, the treatment $\mathrm{N}_{3}$ resulted in significantly higher dry matter production (148.5 g/plant), LAI at 60 DAS (4.07) and 90 DAS (3.93), respectively as compared to other nitrogen management practices. But, the treatment $100 \% \mathrm{~N}$ as inorganic $\left(\mathrm{N}_{1}\right)$ remained statistically at par with $25 \% \mathrm{~N}+1.5$ t/ha V.C
$\left(\mathrm{N}_{4}\right)$ with respect of LAI at 30 DAS. The results are in accordance with Paramesh et al., (2014). They found that combined application of $50 \%$ RDN through chemical fertilizers + $50 \%$ RDN through vermicompost recorded significantly higher growth and yield component of aerobic rice. Dekhane et al., (2014) also reported that application of $50 \%$ $\mathrm{N}$ through $\mathrm{RDF}+50 \% \mathrm{~N}$ through vermicompost recorded higher growth and yield attributes of rice variety GR 11 as compared to $100 \%$ RDF and $75 \%$ RD of NPK through inorganic $+25 \%$ through vermicompost.

\section{Yield attributes and yield}

All the yield attributes were also significantly influenced by different nitrogen management practices (Table 2). Application of $50 \% \mathrm{~N}$ as inorganic +1.0 t/ha V.C. $\left(\mathrm{N}_{3}\right)$ resulted in significantly higher number of effective tiller/metre (63.0) which was statistically at par with application of $50 \% \mathrm{~N}$ as inorganic + $1.0 \mathrm{t} / \mathrm{ha}$ V.C. $\left(\mathrm{N}_{2}\right)$. The number of effective tiller/metre (62.0) recorded in the treatment $\mathrm{N}_{2}$ remained statistically at par with the treatment $\mathrm{N}_{1}$ (61.2).

Similarly the treatment $\mathrm{N}_{3}$ resulted in significantly higher number of total grains/panicle (88.9) and filled grains/panicle (72.6) which were statistically at par with the treatment $\mathrm{N}_{2}$ with total grains/panicle (87.7) and filled grains/panicle (71.6). Moreover, significantly higher test weight $(19.30 \mathrm{~g})$ recorded in the treatment $\mathrm{N}_{2}$ was statistically at par with the treatment $\mathrm{N}_{3}(19.16 \mathrm{~g})$. These results were in conformity with Dekhane et al., (2014). They reported that application of $50 \% \mathrm{~N}$ through RDF $+50 \% \mathrm{~N}$ through vermicompost recorded higher growth and yield attributes of rice variety GR 11 as compared to $100 \%$ RDF and $75 \%$ RD of NPK through inorganic $+25 \%$ through vermicompost. 
Table.1 Growth of rice as influenced by micro climatic regimes and nitrogen management (Pooled data of 2 years)

\begin{tabular}{|c|c|c|c|c|}
\hline Treatments & $\begin{array}{l}\text { Plant Height } \\
\text { (cm) }\end{array}$ & $\begin{array}{l}\text { Dry matter production } \\
\text { (g/plant) at harvest }\end{array}$ & LAI at 60 DAS & LAI at 90 DAS \\
\hline \multicolumn{5}{|l|}{ Micro climatic regimes (M) } \\
\hline$M_{1}$ (1 April) & 140.2 & 152.9 & 4.24 & 3.83 \\
\hline$M_{2}(15$ April $)$ & 132.7 & 149.0 & 3.80 & 3.72 \\
\hline $\mathbf{M}_{3}(1$ May $)$ & 129.2 & 141.9 & 3.69 & 3.64 \\
\hline $\mathrm{M}_{4}$ (15 May) & 124.2 & 130.8 & 3.48 & 3.49 \\
\hline S.Em. $( \pm)$ & 0.56 & 0.71 & 0.01 & 0.01 \\
\hline CD (0.05) & 1.62 & 2.0 & 0.05 & 0.05 \\
\hline \multicolumn{5}{|l|}{ Nitrogen Management (M) } \\
\hline $\mathrm{N}_{1}(100 \% \mathrm{~N}$ as Inorganic ) & 132.3 & 143.1 & 3.67 & 3.59 \\
\hline $\mathrm{N}_{2}(75 \% \mathrm{~N}+0.5 \mathrm{t} / \mathrm{ha} \mathrm{V} . \mathrm{C})$ & 135.5 & 146.6 & 3.85 & 3.69 \\
\hline $\mathrm{N}_{3}(50 \% \mathrm{~N}+1.0$ t/ha V.C. $)$ & 134.1 & 148.5 & 4.07 & 3.93 \\
\hline $\mathrm{N}_{4}(25 \% \mathrm{~N}+1.5 \mathrm{t} / \mathrm{ha}$ V.C. $)$ & 124.3 & 136.3 & 3.62 & 3.47 \\
\hline S.Em. $( \pm)$ & 0.56 & 0.71 & 0.01 & 0.01 \\
\hline CD (0.05) & 1.62 & 2.0 & 0.05 & 0.05 \\
\hline \multicolumn{5}{|l|}{$\mathbf{M} \times \mathbf{N}$} \\
\hline S.Em. $( \pm)$ & 2.19 & 2.83 & 0.07 & 0.08 \\
\hline CD (0.05) & NS & NS & NS & NS \\
\hline $\mathrm{CV}(\%)$ & 5.1 & 6.0 & 6.1 & 6.3 \\
\hline
\end{tabular}


Table.2 Yield attributes and yields of rice as influenced by micro climatic regimes and nitrogen management (Pooled data of 2 years)

\begin{tabular}{|c|c|c|c|c|c|c|}
\hline Treatments & $\begin{array}{l}\text { No. of effective tillers / } \\
\text { running meter }\end{array}$ & $\begin{array}{c}\text { No. of total } \\
\text { grains/panicle }\end{array}$ & $\begin{array}{c}\text { No. of filled } \\
\text { grains/panicle }\end{array}$ & $\begin{array}{c}\text { Test } \\
\text { weight } \\
\text { (gm) }\end{array}$ & $\begin{array}{c}\text { Grain } \\
\text { yield } \\
\text { (q/ha) }\end{array}$ & $\begin{array}{l}\text { Straw yield } \\
\text { (q/ha) }\end{array}$ \\
\hline \multicolumn{7}{|l|}{ Micro climatic regimes $(\mathbf{M})$} \\
\hline$M_{1}(1$ April $)$ & 65.2 & 93.0 & 73.0 & 20.35 & 30.53 & 55.68 \\
\hline$M_{2}(15$ April) & 60.1 & 87.8 & 70.2 & 19.06 & 27.44 & 53.65 \\
\hline $\mathbf{M}_{3}$ (1 May ) & 57.8 & 83.8 & 68.2 & 18.32 & 26.61 & 51.19 \\
\hline$M_{4}$ (15 May) & 56.4 & 79.5 & 63.9 & 17.54 & 24.14 & 47.77 \\
\hline S.Em. $( \pm)$ & 0.40 & 0.45 & 0.43 & 0.06 & 0.27 & 0.43 \\
\hline CD (0.05) & 1.17 & 1.31 & 1.24 & 0.19 & 0.66 & 1.22 \\
\hline \multicolumn{7}{|l|}{ Nitrogen Management (N) } \\
\hline $\mathrm{N}_{1}(\mathbf{1 0 0 \%} \mathrm{N}$ as Inorganic ) & 61.2 & 85.2 & 68.9 & 18.76 & 26.89 & 52.38 \\
\hline $\mathrm{N}_{2}(75 \% \mathrm{~N}+0.5 \mathrm{t} / \mathrm{ha} \mathrm{V} . \mathrm{C})$ & 62.0 & 87.7 & 71.6 & 19.30 & 28.25 & 54.31 \\
\hline $\mathrm{N}_{3}(50 \% \mathrm{~N}+1.0 \mathrm{t} / \mathrm{ha}$ V.C. $)$ & 63.0 & 88.9 & 72.6 & 19.16 & 28.91 & 54.64 \\
\hline $\mathrm{N}_{4}(25 \% \mathrm{~N}+1.5 \mathrm{t} / \mathrm{ha}$ V.C. $)$ & 53.2 & 82.1 & 62.1 & 18.05 & 24.68 & 47.68 \\
\hline S.Em. $( \pm)$ & 0.40 & 0.45 & 0.43 & 0.06 & 0.27 & 0.43 \\
\hline CD (0.05) & 1.17 & 1.31 & 1.24 & 0.19 & 0.66 & 1.22 \\
\hline \multicolumn{7}{|l|}{$M \times N$} \\
\hline S.Em. $( \pm)$ & 1.62 & 1.82 & 1.72 & 0.28 & 0.92 & 1.70 \\
\hline CD (0.05) & NS & NS & NS & NS & NS & NS \\
\hline $\mathrm{CV}(\%)$ & 8.1 & 6.3 & 7.4 & 4.3 & 10.1 & 9.7 \\
\hline
\end{tabular}


Significantly higher yield attributes viz., number of panicle $/ \mathrm{m}^{2}$, panicle length; panicle weight and 1000 grain weight due to application of inorganic fertilizers along with vermicompost were reported by Arun Kumar et al., (2014).

Results also showed that the treatment $\mathrm{N}_{3}$ resulted in significantly higher grain yield $(28.91 \mathrm{q} / \mathrm{ha})$ which was statistically at par with $\mathrm{N}_{2}(28.25 \mathrm{q} / \mathrm{ha})$. Moreover $\mathrm{N}_{3}$ resulted in significantly higher straw yield $(54.63 \mathrm{q} / \mathrm{ha})$ which was statistically at par with $\mathrm{N}_{2}$ $(54.31 \mathrm{q} / \mathrm{ha})$. These results were in conformity with Dekhane et al., (2014). They reported that application of $50 \% \mathrm{~N}$ through RDF + $50 \% \mathrm{~N}$ through vermicompost recorded higher growth and yield attributes of rice variety GR 11 as compared to $100 \% \mathrm{RDF}$ and $75 \%$ RD of NPK through inorganic $+25 \%$ through vermicompost. Significantly higher yield attributes viz., number of panicle $/ \mathrm{m}^{2}$, panicle length; panicle weight and 1000 grain weight due to application of inorganic fertilizers along with vermicompost were reported by Arun Kumar et al., (2014).

\section{Interaction effect}

The interaction between micro climatic regimes and nitrogen management failed to bring about any significant effect on growth parameters; yield attributes and yields of rice (Table 1 and 2).

From the study it can be concluded that sowing of direct seeded rice on 1 April with the application of $50 \% \mathrm{~N}$ as inorganic along with vermicompost @ 1.0 t/ha may be suggested under agro climatic condition of Tinsukia, Assam.

\section{References}

Akbar, N., Iqbal, A., Khan, H. Z., Hanif, M. K and Bashir, M. U. 2010. Effect of different sowing dates on the yield and yield components of direct seeded fine rice (Oryza sativa L.) J. Plant Breed. Crop Sci. 2(10):312-315

Arun Kumar, R., Meena, N., Yadav, L. and Gilotia, Y. K. 2014. Effect of organic and inorganic sources of nutrient on yield, yield attributes and nutrient uptake of rice cv. PRH-10. International Quart. J. Life Sci. 9(2): 595-597.

Bashir, M.U., Akber, N., Iqbal, A. and Zaman, H. 2010. Effect of different sowing dates on yield and yield components of direct seeded coarse rice (Oryza sativa L.) Pakistan J. Agric. Sci. 47(4): 361-365.

Dahiya, S., Punia, S. S., Singh, J., Kakraliya, S. K., Singh, B., Jat, H. S. and Malik, R. K. 2017. Yield and Yield Attributes as Affected by Different Sowing Dates and Different Maturity Classes Cultivar on Direct Seeded Rice. Chem. Sci. Rev Lett. 6(21):149-152.

Dawadi, K. P. and Chaudhary, N. K. 2013. Effect of sowing dates and varieties on yield and yield attributes of direct seeded rice in Chitwan, Nepal. International J. Agric. Res. Sci. 2(4): 095-102

Dekhane, S. S., Patel, D. J., Jadhav, P. B., Kireeti, A., Patil, N. B., Harad, N. B. and Jadhav, K. P. 2014. Effect of organic and inorganic fertilizer on growth and yield of paddy cv GR 11 . Intern J. Inform. Res. \& Rev. 1(2): 026028

Khalifa, A. A. and El-Rewainy, I. M. 2012. Study some physiological characters, yield and yield component for five new rice varieties under different sowing dates. Adv. Appl. Sci. Res. 3(1): 440445.

Khalifa, A. A. B. 2009. Physiological evaluation of some hybrid rice varieties under different sowing dates. Australian 
J. Crop Sci. 3(3): 178-183.

Panse, V.G. and Sukhatme, P.V. (1985). Statistical Methods for Agriculture Workers, Indian Council of Agricultural Research, New Delhi.

Rai, H. K. and Kushwaha, H.S. 2008. Effect of planting dates and soil water regimes on growth and yield of upland rice. Oryza. 45(1):129-132.

Singh, A.K., Chandra, N. and Bharti, R.C. 2012. Effects of genotype and planting time on phenology and performance of rice (Oryza sativa L.). Vegetos 25(1):151-156.

Vishwakarma, A., Singh, J. K., Sen, A., Bohra, J. S. and Singh, S. 2016. Effect of transplanting date and age of seedlings on growth, yield and quality of hybrids under system of rice (Oryza sativa L.) intensification and their effect on soil fertility. Indian J. Agric. Sci., 86(5): 34-39.

\section{How to cite this article:}

Ahmed, P., M. Saikia, K. Pathak, S. Dutta and Sarmah, A.C. 2019. Effect of Microclimatic Regimes and Nitrogen Management on Growth and Yield of Direct Seeded Rice (Oryza sativa L.) under Rainfed Condition. Int.J.Curr.Microbiol.App.Sci. 8(02): 1351-1358. doi: https://doi.org/10.20546/ijcmas.2019.802.158 